\title{
PERAMALAN HARGA TELUR AYAM RAS DI JAKARTA TIMUR BERBASIS JARINGAN SYARAF TIRUAN
}

\author{
Nurfia Oktaviani Syamsiah
}

\author{
Fakultas Teknologi Informasi Universitas Bina Sarana Informatika \\ Jl. Kamal Raya No.18, Cengkareng Barat, Kecamatan Cengkareng, Kota Jakarta Barat, DKI Jakarta
} nurfia.nos@bsi.ac.id

\begin{abstract}
Abstrak-Penelitian ini membahas tentang pemanfaatan jaringan syaraf tiruan untuk peramalan harga telur ayam ras di Jakarta Timur. Data harga yang digunakan adalah data time series harian. Metode yang dipilih adalah Jaringan syaraf tiruan dengna 2 fungsi aktivasi, yakni sigmoid biner dan sigmoid bipolar dengan memanfaatkan Tools Rapidminer Studio mulai dari tahapan pertama hingga tahapan akhir. Eksperimen dilakukan dengan melakukan perubahan pada beberapa parameter neural network seperti jumlah hidden node, training cycle, learning rate maupun jumlah momentum. Penentuan hidden layer diupayakan semaksimal mungkin bertujuan untuk menghindari terjadinya permasalahan Overfitting dan Underfitting. Hasil yang dicapai, bahwasanya RMSE terkecil diperoleh dari penggunaan fungsi aktivasi sigmoid biner dengan nilai 0.033 . dan arsitektur terbaik yakni 7 input, 2 hidden node dan 1 output. Penelitian ini menunjukkan hasil bahwa jaringan syaraf tiruan memberikan hasil yang cukup baik bagi peramalan data harga telur ayam ras di Jakarta Timur yang datanya bersifat time series univariat.
\end{abstract}

Kata Kunci-Jaringan Syaraf Tiruan, Telur, Harga, Peramalan

Abstract-This research discusses the use of artificial neural networks for forecasting the price of eggs in East Jakarta. Price data used is daily time series data. The method chosen was an artificial neural network with 2 activation functions, namely binary sigmoid and bipolar sigmoid by utilizing Rapid miner Studio Tools from the first stage to the final stage. Experiments carried out by making changes to several neural network parameters such as the number of hidden nodes, training cycle, learning rate and the amount of momentum. Determination of hidden layers is done as much as possible aims to avoid the occurrence of over fitting and under fitting problems. The results achieved, that the smallest RMSE obtained from the use of the binary sigmoid activation function with a value of 0.033 . and the best architecture is 7 inputs, 2 hidden nodes and 1 output. This study shows the results that the artificial neural network gives a pretty good result for forecasting the price of chicken eggs in East Jakarta, the data are univariate time series data

Keywords-Neural Network, Eggs, Price, Forecasting

\section{PENDAHULUAN}

Salah satu produk pangan pokok yang mempunyai harga relatif berfluktuasi adalah telur ayam. Seperti daging ayam dan sapi, telur ayam merupakan salah satu pangan pokok yang mempunyai kandungan protein cukup tinggi namun dengan harga cukup terjangkau oleh semua lapisan masyarakat. Oleh sebab itu, stabilisasi harga telur merupakan salah satu agenda kebijakan strategis pemerintah [1].

Harga telur selama lima tahun terakhir terus meningkat. Pada tahun 2018, rata-rata harga telur ayam ras lebih tinggi dibandingkan empat tahun sebelumnya dengan fluktuasi harga yang tinggi dengan CV 8,18. Harga telur di tingkat konsumen sedikit lebih fluktuatif dibandingkan di tingkat produsen dengan pola pergerakan yang relatif sama [2].

Berdasarkan data Badan Pusat Statistik, harga ratarata nasional telur ayam ras pada bulan Desember 2018 adalah sebesar Rp26.293/kg. Harga telur ayam ras tersebut mengalami peningkatan sebesar 14,54 persen dibandingkan harga rata-rata telur ayam ras pada bulan
November 2018, sebesar Rp22.955/kg. Jika dibandingkan dengan harga pada periode yang sama tahun lalu (Desember 2017) sebesar Rp24.040/kg, maka harga telur ayam ras pada Desember 2018 mengalami peningkatan sebesar 9,37 persen [3].

Fluktuasi harga bahan pokok yang tidak terkendali dapat menyebabkan kerugian bagi konsumen maupun produsen. Salah satu langkah untuk mengatasi permasalahan tersebut yaitu dengan membuat prediksi harga yang akurat sehingga tindakan preventif dapat dilakukan untuk meminimalkan gejolak harga [4]. Fluktuasi harga memerlukan peramalan yang akan memberikan informasi yang relevan untuk mengetahui harga dimasa yang akan datang sehingga memberikan informasi yang berguna dalam merumuskan kebijakan ke arah yang lebih baik.

Data harga telur ayam ras yang digunakan berbentuk data runtun waktu (time series), yang dalam penelitian ini diambil dari infopangan.jakarta.go.id . Data runtun waktu (time series) sangatlah menarik karena memungkinkan untuk menemukan nilai periode berikutnya pada sebuah urutan dari nilai masa lalu, 
dengan sedikit kesalahan [5]. Data harga telur ayam ras ini termasuk dalam data berfrekuensi tinggi, dimana terlihat dari periode datanya, yakni data per-hari [6]

Beberapa metode yang banyak digunakan dalam melakukan peramalan data runtun waktu adalah, ARIMA [7], Fuzzy dan Suport Vector Machine [8], serta Jaringan Syaraf Tiruan [9]. Jaringan syaraf tiruan menjadi metode yang cukup banyak digunakan oleh peneliti, baik secara single method maupun hybrid method ataupun penelitian yang bersifat komparasi algoritma [9].

Peramalan time series memiliki dua kategori data, yakni multivariat dan univariat. Data multivariat meramal berdasarkan parameter multi-input (lebih dari 1 variabel). Sedangkan metode univariat hanya mengandalkan nilai saat ini atau masa lalu (1 variabel). Metode kedua relatif lebih efisien karena tidak memerlukan alat pengukuran lainnya selain dataset yang ada. Selain itu, untuk proses kontrol dinamis berkecepatan tinggi, yang memerlukan peramalan jangka pendek, metode univariat lebih efektif karena tidak bergantung pada proses akuisisi data yang berkepanjangan [10]. Penelitian yang memanfaatkan data univariat pun dapat menghasilkan akurasi yang cukup baik [11].

Penggunaan data univariat dapat menggunakan model linier (ARIMA dan Exponential Smoothing) ataupun model nonlinear (Jaringan Syaraf Tiruan, Support Vector Regression, Decision Tree, ataupun KNearest Neighboard). Model nonlinear dianggap lebih akurat dalam hal menangkap karakteristik nonlinear dan perilaku waktu yang bervariasi [10][12].

Beberapa penelitian sejenis yang dalam hal ini melakukan peramalan harga telur ayam ras, telah dilakukan dengan beberapa metode seperti PSO-NN menghasilkan MAPE terkecil yang didapatkan yaitu $1.01552 \%$ [13], SVR-PSO yang menghasilkan nilai MAPE terkecil sebesar $1.8840 \%$ serta penelitian lainnya yang menggunakan ARIMA dan Holt Winter Exponential Smoothing dengan MAPE 4.061\% [14].

Penelitian ini menggunakan data univariat dan metode Jaringan Syaraf Tiruan dalam peramalan harga telur ayam ras di Kota Jakarta Timur. Penelitian ini bertujuan membuktikan kehandalan penggunaan jaringan syaraf, dengan melihat nilai RMSE yang dihasilkan. Serta membandingkan 2 fungsi aktivasi yang digunakan pada model, apakah terdapat perbedaan yang signifikan ataukah kedua model yang dihasilkan tidak memiliki perbedaan.

\section{METODE PENELITIAN}

Data yang digunakan pada penelitian ini adalah data sekunder berupa data time series harian-an yakni data harga telur ayam ras di Kota Jakarta Timur mulai dari Januari 2019 hingga Oktober 2019. Data yang dimaksud terlihat pada Gambar 1.



Gbr. 1 Grafik atas Dataset Harga Telur Ayam Ras

Metode yang dipilih adalah Jaringan Syaraf Tiruan serta memanfaatkan Rapidminer Studio mulai dari tahapan pertama hingga tahapan akhir. Adapun tahapan penelitiannya terlihat pada Gambar 2.



Alur penelitian yang digunakan dalam penelitiaan ini adalah:

A. Menggunakan dataset harga telur ayam ras hari-an, dengan operator Read Excel

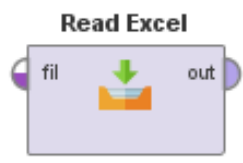

Gbr. 3 Operator Read Excel pada Rapidminer

B. Tahap selanjutnya adalah mengatur peran masingmasing atribut yang terdapat pada dataset. Pada RapidMiner yang digunakan adalah operator set role yang berfungsi mengubah peran suatu atribut yaitu attribute hari dari atribut regular menjadi atribut khusus yaitu sebagai id. 


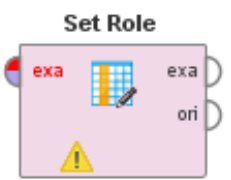

Gbr. 4 Operator Set Role pada Rapidminer

C. Selanjutnya dilakukan normalisasi dataset memanfaatkan operator normalize. Normalisasi diterapkan pada atribut harga, nilai atribut diubah menjadi 0-1 untuk fungsi aktivasi sigmoid biner, dan -1 hingga 1 untuk fungsi aktivasi sigmoid bipolar

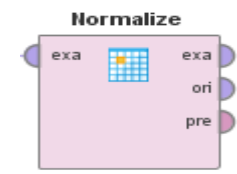

Gbr. 5 Operator Normalize

D. Tahap berikutnya adalah proses windowing, yang berefek pada pengelompokan data menjadi 7 data input dan 1 data output. Data input merupakan data 7 hari sebelumnya dan data output adalah data di hari berikutnya.

E. Tahap selanjutnya adalah training dan testing dengan jaringan syaraf tiruan. Data training dan testing dibagi menggunakan K-Fold CrossValidation. Jumlah fold yang digunakan adalah 10 karena 10 fold cross validation adalah pilihan terbaik untuk mendapatkan hasil validasi yang akurat. [15].

F. Tahap akhir adalah evaluasi hasil peramalan, dengan menggunakan operator performance untuk melihat nilai Root Mean Square Error (RMSE) sehingga bisa dianalisis tingkat akurasinya. Perbedaan yang signifikan dari kedua model akan dibandingkan menggunakan T-Test. Jika nilai uji $\mathrm{T}$ adalah lebih kecil dari 0,05 maka Ho ditolak [16].

\section{HASIL DAN PEMBAHASAN}

Eksperimen dilakukan dengan melakukan perubahan pada beberapa parameter neural network seperti jumlah hidden layer, training cycle, learning rate maupun jumlah momentum.

Terdapat beberapa cara menentukan jumlah hidden layer, dan mayoritas ditentukan dari jumlah input dan output. Dengan meningkatkan jumlah hidden layer, akurasi dapat ditingkatkan tetapi kompleksitas neural network dan waktu training pun ikut meningkat. Untuk mengatasinya dapat dilakukan dengan menggunakan learning rate yang cukup besar agar terjadi konvergensi, dalam upaya untuk mempercepat waktu training [17]. Sedangkan untuk momentum, akan berbanding terbalik dengan nilai learning rate. Jadi, jika menggunakan learning rate yang besar maka nilai momentum akan dikecilkan.

Model Jaringan Syaraf Tiruan terbaik hanya dapat dihasilkan dengan cara trial-error, yakni mengubah nilai-nilai setiap parameter secara acak hingga dihasilkan model terbaik dengan akurasi tertinggi [18][19].

Percobaan pertama menggunakan fungsi aktivasi Sigmoid Biner dimulai dengan 1 hidden sehingga dihasilkan model terbaik dengan RMSE terkecil seperti pada Tabel 1.

Hasil pada Tabel 1, terdapat 1 arsitektur dengan nilai RMSE terkecil, yakni 0.033. Arsitektur tersebut sesuai dengan konsep, yakni meningkatkan jumlah hidden, training yang tidak terlalu banyak dan nilai learning rate yang berbanding terbalik dengan momentum. Arsitektur yang terpilih adalah dengan 2 hidden node, 1000 training cycle, nilai learning rate terbesar 0.01 dan momentum yang paling kecil yakni 0.001. Adapun arsitekturnya terlihat pada gambar 6 .

TABLE I

HASIL EKSPERIMEN DENGAN SIGMOID BINER

\begin{tabular}{|c|c|c|c|c|}
\hline $\begin{array}{l}\text { Hidden } \\
\text { Node }\end{array}$ & $\begin{array}{l}\text { Training } \\
\text { Cycles }\end{array}$ & $\begin{array}{l}\text { Learning } \\
\text { Rate }\end{array}$ & Momentum & RMSE \\
\hline \multirow[t]{21}{*}{1} & 200 & 0.001 & 0.9 & 0.042 \\
\hline & 200 & 0.001 & 0.1 & 0.168 \\
\hline & 200 & 0.001 & 0.05 & 0.169 \\
\hline & 200 & 0.001 & 0.001 & 0.170 \\
\hline & 500 & 0.001 & 0.9 & 0.036 \\
\hline & 500 & 0.001 & 0.1 & 0.087 \\
\hline & 500 & 0.001 & 0.05 & 0.094 \\
\hline & 500 & 0.001 & 0.001 & 0.101 \\
\hline & 1000 & 0.001 & 0.9 & 0.034 \\
\hline & 1000 & 0.001 & 0.1 & 0.045 \\
\hline & 1000 & 0.001 & 0.05 & 0.045 \\
\hline & 1000 & 0.001 & 0.001 & 0.046 \\
\hline & 200 & 0.01 & 0.9 & 0.065 \\
\hline & 500 & 0.01 & 0.9 & 0.060 \\
\hline & 500 & 0.01 & 0.1 & 0.036 \\
\hline & 500 & 0.01 & 0.05 & 0.036 \\
\hline & 500 & 0.01 & 0.001 & 0.036 \\
\hline & 1000 & 0.01 & 0.9 & 0.059 \\
\hline & 1000 & 0.01 & 0.1 & 0.034 \\
\hline & 1000 & 0.01 & 0.05 & 0.034 \\
\hline & 1000 & 0.01 & 0.001 & 0.034 \\
\hline \multirow[t]{21}{*}{2} & 200 & 0.001 & 0.9 & 0.042 \\
\hline & 200 & 0.001 & 0.1 & 0.165 \\
\hline & 200 & 0.001 & 0.05 & 0.167 \\
\hline & 200 & 0.001 & 0.001 & 0.168 \\
\hline & 500 & 0.001 & 0.9 & 0.036 \\
\hline & 500 & 0.001 & 0.1 & 0.064 \\
\hline & 500 & 0.001 & 0.05 & 0.069 \\
\hline & 500 & 0.001 & 0.001 & 0.075 \\
\hline & 1000 & 0.001 & 0.9 & 0.034 \\
\hline & 1000 & 0.001 & 0.1 & 0.044 \\
\hline & 1000 & 0.001 & 0.05 & 0.044 \\
\hline & 1000 & 0.001 & 0.001 & 0.045 \\
\hline & 200 & 0.01 & 0.9 & 0.061 \\
\hline & 500 & 0.01 & 0.9 & 0.065 \\
\hline & 500 & 0.01 & 0.1 & 0.036 \\
\hline & 500 & 0.01 & 0.05 & 0.036 \\
\hline & 500 & 0.01 & 0.001 & 0.036 \\
\hline & 1000 & 0.01 & 0.9 & 0.067 \\
\hline & 1000 & 0.01 & 0.1 & 0.034 \\
\hline & 1000 & 0.01 & 0.05 & 0.034 \\
\hline & 1000 & 0.01 & 0.001 & 0.033 \\
\hline
\end{tabular}


Input

Hidden 1

Output

Page | 68

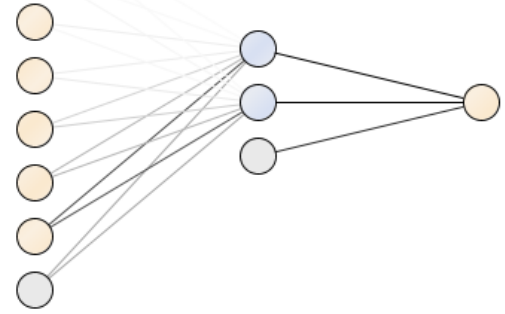

Gbr. 6 Arsitektur Sigmoid Biner dengan RMSE terpilih

Percobaan kedua menggunakan fungsi aktivasi sigmoid bipolar dengan nilai awal 1 hidden sehingga dihasilkan model terbaik dengan RMSE terkecil seperti pada Tabel 2.

TABLE II

HASIL EKSPERIMEN DENGAN SIGMOID BIPOLAR

\begin{tabular}{|c|c|c|c|c|}
\hline $\begin{array}{l}\text { Hidden } \\
\text { Node }\end{array}$ & $\begin{array}{l}\text { Training } \\
\text { Cycles }\end{array}$ & $\begin{array}{l}\text { Learning } \\
\text { Rate }\end{array}$ & Momentum & RMSE \\
\hline \multirow[t]{21}{*}{1} & 200 & 0.001 & 0.9 & 0.075 \\
\hline & 200 & 0.001 & 0.1 & 0.214 \\
\hline & 200 & 0.001 & 0.05 & 0.229 \\
\hline & 200 & 0.001 & 0.001 & 0.243 \\
\hline & 500 & 0.001 & 0.9 & 0.068 \\
\hline & 500 & 0.001 & 0.1 & 0.097 \\
\hline & 500 & 0.001 & 0.05 & 0.099 \\
\hline & 500 & 0.001 & 0.001 & 0.100 \\
\hline & 1000 & 0.001 & 0.9 & 0.067 \\
\hline & 1000 & 0.001 & 0.1 & 0.083 \\
\hline & 1000 & 0.001 & 0.05 & 0.084 \\
\hline & 1000 & 0.001 & 0.001 & 0.085 \\
\hline & 200 & 0.01 & 0.9 & 0.116 \\
\hline & 500 & 0.01 & 0.9 & 0.119 \\
\hline & 500 & 0.01 & 0.1 & 0.069 \\
\hline & 500 & 0.01 & 0.05 & 0.069 \\
\hline & 500 & 0.01 & 0.001 & 0.068 \\
\hline & 1000 & 0.01 & 0.9 & 0.120 \\
\hline & 1000 & 0.01 & 0.1 & 0.067 \\
\hline & 1000 & 0.01 & 0.05 & 0.067 \\
\hline & 1000 & 0.01 & 0.001 & 0.067 \\
\hline \multirow[t]{21}{*}{2} & 200 & 0.001 & 0.9 & 0.074 \\
\hline & 200 & 0.001 & 0.1 & 0.164 \\
\hline & 200 & 0.001 & 0.05 & 0.179 \\
\hline & 200 & 0.001 & 0.001 & 0.193 \\
\hline & 500 & 0.001 & 0.9 & 0.066 \\
\hline & 500 & 0.001 & 0.1 & 0.094 \\
\hline & 500 & 0.001 & 0.05 & 0.095 \\
\hline & 500 & 0.001 & 0.001 & 0.095 \\
\hline & 1000 & 0.001 & 0.9 & 0.065 \\
\hline & 1000 & 0.001 & 0.1 & 0.080 \\
\hline & 1000 & 0.001 & 0.05 & 0.081 \\
\hline & 1000 & 0.001 & 0.001 & 0.082 \\
\hline & 200 & 0.01 & 0.9 & 0.113 \\
\hline & 500 & 0.01 & 0.9 & 0.117 \\
\hline & 500 & 0.01 & 0.1 & 0.067 \\
\hline & 500 & 0.01 & 0.05 & 0.067 \\
\hline & 500 & 0.01 & 0.001 & 0.067 \\
\hline & 1000 & 0.01 & 0.9 & 0.112 \\
\hline & 1000 & 0.01 & 0.1 & 0.066 \\
\hline & 1000 & 0.01 & 0.05 & 0.066 \\
\hline & 1000 & 0.01 & 0.001 & 0.066 \\
\hline
\end{tabular}

Hasil pada Tabel 2, terdapat 1 arsitektur dengan nilai RMSE terkecil, yakni 0.065. Arsitektur tersebut sesuai dengan konsep arsitektur jaringan syaraf yang terbaik, yakni dengan menambah jumlah hidden node, meningkatkan jumlah training dan nilai learning rate yang berbanding terbalik dengan momentum. Arsitektur yang terpilih tersebut tersusun atas 2 hidden node, 1000 training cycle, nilai learning rate terbesar 0.001 dan momentum 0.9. Adapun arsitekturnya sama seperti yang dihasilkan pada fungsi sigmoid biner, terlihat pada gambar 6 .

Tahapan selanjutnya dilakukan uji beda menggunakan t-Test. Berdasarkan hasil uji T-test pada gambar 7, dihasilkan nilai uji $\mathrm{T}$ yang lebih kecil dari 0.05 sehingga terdapat perbedaan yang signifikan diantara kedua model. Maka dengan ini H0 ditolak, dan H1 diterima.

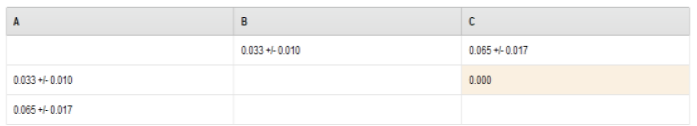

Gbr. 7 Hasil Uji T-Test atas 2 model dengan RMSE terkecil

\section{IV.PENUTUP}

Pada penelitian ini telah dilakukan penerapan Jaringan Syaraf Tiruan untuk peramalan data harga telur ayam ras di Jakarta Timur, dengan tipe data time series yang bersifat univariat. Eksperimen telah dilakukan dengan membandingkan 2 hasil dari penggunaan fungsi aktivasi yang berbeda, yakni sigmoid biner dan sigmoid bipolar. RMSE terendah sebesar 0.033 dihasilkan oleh fungsi sigmoid biner. Sedangkan arsitektur neural network yang menghasilkan RMSE terendah memiliki parameter yang sama persis, yakni 7 input, 2 hidden node, 1 output dengan nilai parameter learning cycle 1000 , learning rate 0.01 dan momentum 0.001. Melalui hasil t-Test menunjukan adanya perbedaan yang signifikan dari penerapan 2 fungsi aktivasi tersebut.

\section{REFERENSI}

[1] Y. Nuryati and Y. H. Nur, "Variabilitas Harga Telur Ayam Ras di Indonesia," Bul. Ilm. Litbang Perdagang., vol. 6, no. 2, pp. 235-252, 2012.

[2] N. Ilham and Saptana, "FLUKTUASI HARGA TELUR AYAM RAS DAN FAKTOR PENYEBABNYA Fluctuations in the Prices of Chicken Eggs and Their Causes," Anal. Kebijak. Pertan., vol. 17, no. 1, pp. 27-38, 2019.

[3] Badan Pengkajian dan Pengembangan Perdagangan, "Analisis Perkembangan Harga Bahan Pokok di Pa sar Domestik dan Internasional,” Jakarta, 2018.

[4] M. A. Rasyidi, "Prediksi Harga Bahan Pokok Nasional Jangka Pendek Menggunakan ARIMA," J. Inf. Syst. Eng. Bus. Intell., vol. 3, no. 2, p. 107, 2017.

[5] A. Tealab, H. Hefny, and A. Badr, "Forecasting of nonlinear time series using ANN," Futur. Comput. Informatics J., vol. 2, no. 1, pp. 39-47, 2017. 
[6] S. Makridakis, E. Spiliotis, and V. Assimakopoulos, "The M4 Competition: 100,000 time series and 61 forecasting methods," Int. J. Forecast., no. xxxx, 2019.

[7] H. V. Nguyen, M. A. Naeem, N. Wichitaksorn, and R. Pears, "A smart system for short-term price prediction using time series models R," Comput. Electr. Eng., vol.

Page|69 76, pp. 339-352, 2019.

[8] X. Xu, R. Law, W. Chen, and L. Tang, "Forecasting tourism demand by extracting fuzzy Takagi e Sugeno rules from trained SVMs," CAAI Trans. Intell. Technol., vol. 1, no. 1, pp. 30-42, 2016.

[9] A. Gouda, H. Hefny, and A. Badr, "Time Series Forecasting using Artificial Neural Networks Methodologies: A Systematic Review," Futur. Comput. Informatics J., vol. 3, no. 2, pp. 334-340, 2018.

[10] M. Majidpour, H. Nazaripouya, P. Chu, H. Pota, and R. Gadh, "Fast Univariate Time Series Prediction of Solar Power for Real-Time Control of Energy Storage System," Forecasting, vol. 1, no. 1, pp. 107-120, 2018.

[11] T. Phan, "Comparative Study on Univariate Forecasting Methods for Meteorological Time Series," in 26th European Signal Processing Conference (EUSIPCO), 2018, pp. 2380-2384.

[12] K. Y. Chen, "Combining linear and nonlinear model in forecasting tourism demand," Expert Syst. Appl., vol. 38, no. 8, pp. 10368-10376, 2011.

[13] N. Sylviani and A. A. Soebroto, "Peramalan Harga Pasar Telur Ayam Ras Di Kota Malang Dengan Menggunakan Metode 'PSO-NN ," J. Pengemb. Teknol. Inf. dan Ilmu Komput. Univ. Brawijaya, vol. 2, no. 12, pp. 6737-6745, 2018.

[14] R. P. Destiarni, "Peramalan Harga Telur Ayam Ras pada Hari Besar Keagamaan di Pasar Jawa Timur," Agridevina, vol. 7, no. 1, pp. 62-76, 2018.

[15] R. Kohavi, "A Study of Cross-Validation and Bootstrap for Accuracy Estimation and Model Selection," in Appears in the International Joint Conference on Arti?cial Intelligence (IJCAI), 1995, vol. 2, no. 14, pp. 1137-1143.

[16] A. R. Kadafi, "Perbandingan Algoritma Klasifikasi Untuk Penjurusan Siswa SMA," J. ELTIKOM, vol. 2, no. 2, pp. 67-77, 2018.

[17] D. R. Wilson and T. R. Martinez, "The need for small learning rates on large problems," in International Joint Conference on Neural Networks (IJCNN), 2001, vol. 1, pp. 115-119.

[18] G. Astray, J. C. Mejuto, V. Martinez, I. Nevares, M. Alamo-sanza, and J. Simal-gandara, "Prediction Models to Control Aging Time in," Molecules, vol. 24, no. 5, pp. 1-11, 2019.

[19] C. W. Dawson and R. L. Wilby, "Hydrological modelling using artificial neural networks," Prog. Phys. Geogr., vol. 1, no. 25, pp. 80-108, 2001. 